\title{
PROFESIONALISME KONSELOR SEKOLAH DALAM PELAYANAN GENERASI MILENIAL
}

\author{
Isna Ni'matus Sholihah
}

Bimbingan dan Konseling, SMK Negeri 2 Bojonegoro, email: neoisnaisme@gmail.com

Titin Handayani

Bimbingan dan Konseling, SMK Negeri Dander Bojonegoro, email: titinhandayani192@gmail.com

\author{
Bambang Tejo Baskoro
}

Bimbingan dan Konseling, SMK Negeri Pagerwojo Tulungagung, email: b4mbank@yahoo.co.id

\begin{abstract}
Abstrak
Setiap profesi memiliki kode etik berupa perangkat regulasi perilaku bagi pengemban profesi tersebut. Regulasi inilah yang menjamin pelayanan akan dilakukan dengan profesional. Konselor sekolah masa kini menghadapi tantangan seru yaitu melayani generasi milenial. Generasi ini merupakan generasi yang percaya kepada teknologi, jaga $s$, serba bisa, terbuka pada perubahan, percaya diri, berorientasi tim, kaya informasi, tidak sabaran dan mudah beradaptasi. Pelayanan bimbingan dan konseling perlu mengadaptasi konsep virtual, dalam hal ini adalah layanan digital melalui media sosial demi pelayanan dan referensi maksimal.

Kata Kunci: Profesionalisme, Generasi Milenial, Akuntabilitas, Kompetensi, Etis, Media Sosial
\end{abstract}

\begin{abstract}
Profession has a code of ethics in the form of a behavior regulation tool for the caretaker of the profession. This regulation guarantees that services will be carried out professionally. School counselors face an exciting challenge of serving the millennial generation. This generation is a technology reliant, image driven, multitasking, open to change, confident, team oriented, rich of information, impatient and adaptable. Guidance and counseling services need to adapt the virtual concept, in this case digital services through social media for maximum service and reference.
\end{abstract}

Keywords: Professionalism, Counselors, Millennial Generation, Accountability, Competence, Ethics, Social Media

\section{PENDAHULUAN}

(1) Latar Belakang

Konselor adalah profesi dinamis yang menyesuaikan terhadap perubahan dan perkembangan masyarakat dan dinamika sosial. Tuntutan kinerja dan keefektifan layanan terus disorot. Terlebih permasalahan yang dihadapi peserta didik juga kian beragam. Semua memerlukan kompetensi dan kesigapan konselor dalam memainkan berbagai peran.

Perubahan di Era Mellinium 4.0 menuntut perubah di lingkungan pendidikan, yang mengadopsi kegiatan-kegiatan bercirikan penggunaan teknologi digital serta proses pembelajaran dengan sistem siber (cyber system). Kemampuan Guru BK/Konselor Sekolah mengikuti kemajuan teknologi serta mengembangan peserta didik menjadi sumber daya manusia yang dapat mengendalikan dampak negative serta mengambil peluang dari perkembangan teknologi dan informasi di era milinium 4.0 sangat diharapkan (Firman, 2019).

Generasi terkini yang mendominasi penduduk Indonesia adalah generasi $\mathrm{Y}$ yang lebih dikenal dengan generasi milenial. Generasi ini adalah generasi yang akrab dengan teknologi. Mereka memperoleh infomasi dari berbagai sumber secara bebas dan membuat pandangan mereka tidak terbatas. Peran konselor sekolah disini adalah membangun kedewasaan peserta didik dengan menganalisis dan memberikan pemahaman akan informasi yang diterima dari internet.

Maryulis (2014) melakukan penelitian tentang Pengaruh aktivitas di media sosial terhadap rutinitas blogger Sumatera Barat mendapatkan data bahwa generasi milenial menggunakan kecanggihan teknologi media online dalam menemukan berbagai informasi, Kegiatan umat manusia di seluruh dunia mampu dipantau hanya dalam satu genggaman gawai yakni melalui media 
sosial, seperti instagram (IG), facebook (FB), twitter, dan lain sebagainya. Penggunaan jejaring sosial ini tidak dibatasi ruang, waktu, usia, suku, budaya, dan apapun agama yang dianut.

Fakta bahwa peserta didik/siswa adalah bagian tak terpisahkan dari perkembangan tatanan peradaban manusia yang menjadikan teknologi sebagai sahabat sehari-hari menimbulkan efek dua arah. Disatu sisi, semua hal menjadi mudah dengan adanya aksesbilitas yang tinggi terhadap informasi terkini. Sisi sebaliknya permasalahan seperti nomophobia (kecanduan gadget), phubbing (tindakan acuh tak acuh terhadap lingkungan karena fokus terhadap gadget), cyber bullying, degradasi moral akibat akses pornografi secara mudah juga membayangi dan menyebabkan hambatan tercapainya tujuan pendidikan yang diselenggarakan di sekolah.

Bimbingan dan konseling yang merupakan komponen tak terpisahkan, bagian integral dari sistem pendidikan di sekolah perlu mengambil langkah praktis dalam pencegahan,pendampingan dan reduksi efek negatif teknologi ini. Konselor menghadapi kondisi berupa tantangan bagaimana mengajarkan dan menanamkan pada diri siswa agar bisa melakukan resiliensi yaitu kemampuan individu untuk menyesuaikan diri secara luwes menghadapi tantangan internal dan eksternal atau menyesuaikan diri dengan permasalahan yang dihadapinya. Profesionaisme konselor dipertaruhkan. Untuk itulah, pelayanan generasi milenial ini memerlukan akuntabilitas yang tinggi, penguasaan kompetensi, etis dan dilakukan melalui media sosial yang sedang in atau up to date.

\section{(2) hasil kajian pustaka}

\section{Profesionalisme}

Pengertian Profesionalisme menurut Wikipedia ialah sifat-sifat (kemampuan, kemahiran, cara pelaksanaan sesuatu dan lain-lain) sebagaimana yang sewajarnya terdapat pada atau dilakukan oleh seorang professional. Sedangkan Siagian (2009) menjelaskan profesionalisme merupakan suatu keandalan dan keahlian dalam pelaksanaan tugas sehingga tugas itu terlaksana dengan mutu tinggi, waktu yang tepat cermat dan juga dengan menggunakan prosedur yang mudah dipahami dan diikuti oleh pelanggan.

Anoraga (2009) menyatakan profesionalisme lebih kepada sebuah cara bagaimana menjalankan suatu profesi untuk keuntungan atau sumber penghidupan. Atmosoeprapto dalam Kurniawan (2005) menyatakan profesionalisme merupakan cerminan dari kemampuan (competency) yaitu mempunyai pengetahuan (knowledge) keterampilan (skill), bisa melakukan (ability) ditunjang dengan pengalaman (experience) yang tidak mungkin muncul tiba-tiba tanpa melalui perjalanan waktu.
Sedangkan Harefa (2004) dalam bukunya Membangkitkan roh/etos profesionalisme berpendapat profesionalisme adalah pertama-tama soal sikap. Sikap yang diwakili keterampilan tinggi yang dimiliki seseorang, pemberian jasa yang berorietasi pada kepentingan umum, adanya pengawasan yang ketat atas perilaku kerja dan juga sistem balas jasa yang merupakan lambang prestasi kerja.

\section{Konselor Sekolah}

Pengertian tentang konselor sekolah bisa kita temukan dalam tentang Sistem pendidikan Nasional (Sisdiknas) . Konselor sekolah difahami sebagai penyelenggara kegiatan Bimbingan dan Konseling dalam lingkup sekolah. Istilah konselor termaktub dalam Undang-undang Nomor 20 Tahun 2003 dengan menyatakan "konselor adalah pendidik". Sedangkan Peraturan Menteri Pendidikan Nasional Nomor 22 Tahun 2005 menyebutkan bahwa konselor adalah pelaksana pelayanan konseling di sekolah yang sebelumnya dikenal dengan istilah petugas Bimbingan dan Penyuluhan (BP), guru BP/BK dan guru pembimbing.

Istilah konselor sekolah juga ditemukan dalam Surat Keputusan Bersama Mendikbud dan Kepala BAKN No. 0433/P/1993 dan No. 25 Tahun 1993 tentang Petunjuk Pelaksanaan Jabatan Fungsional Guru Pembimbing dan Angka Kreditnya yang menjelaskan bahwa guru pembimbing (konselor sekolah) adalah guru yang mempunyai tugas, tanggung jawab, wewenang dan hak secara penuh dalam kegiatan bimbingan dan konseling terhadap sejumlah peserta didik .

Konselor sekolah adalah guru yang melakukan kegiatan menyusun rencana bimbingan dan konseling, melaksanakan bimbingan dan konseling, mengevaluasi proses dan hasil bimbingan dan konseling serta melakukan tindak lanjut dengan menggunakan dan memanfaatkan hasil evaluasi tersebut. Pelayanan Bimbingan dan Konseling di sekolah merupakan kegiatan untuk membantu peserta didik dalam upaya menemukan jati dirinya, penyesuaian terhadap lingkungan serta dapat merencanakan masa depannya dengan baik. Prayitno (2004) menyebutkan bahwa pada hakikatnya pelaksanaan Bimbingan dan Konseling di sekolah untuk mencapai tri sukses, yaitu: sukses bidang akademik, sukses dalam persiapan karir dan sukses dalam hubungan kemasyarakatan.

\section{Generasi Milenial}

Generasi Milenial adalah generasi yang terlahir setelah generasi $\mathrm{X}$ yaitu manusia yang lahir pada kisaran tahun 1980-2000an. Dapat diartikan milenials adalah generasi muda yang berumur 18-38 pada tahun ini.

Generasi milenial memiliki karakter tersendiri. Karakteristik dan nilai-nilai budaya generasi milenial yang ditunjukkan siswa SMA (Sekolah Menengah Atas) di Indonesia, antara lain, adalah menjadikan teknologi sebagai bagian dari gaya hidup atau lifestyle, dan sebagai generasi yang ternaungi atau sheltered, karena mereka 
lahir dari orang tua yang terdidik. Mereka juga multitalented, multi-languages, lebih ekspresif, dan eksploratif. Pandangan generasi milenial terhadap hakekat hidup adalah selalu yakin, optimistik, percaya diri, menginginkan kepraktisan, dan segala sesuatunya serba instan. Generasi ini berpendapat bahwa hakekat kerja adalah menganggap prestasi merupakan sesuatu yang harus dicapai; bekerja lebih interaktif melalui kerjasama tim; kolaborasi dan kelompok berpikir; dilakukan secara mandiri dan tersturuktur dalam penggunaan teknologi, khususnya communication gadget; serta dalam akses internet. Generasi milenial lebih menyukai petunjuk visual atau gambar (Ayun, 2015 dalam Sutijono, 2018).

\section{Akuntabilitas}

$\begin{array}{ccc}\text { Akuntabilitas } & \text { berasal dari bahasa inggris } \\ \text { artinya } & \text { keadaan } & \text { untuk }\end{array}$ dipertanggungjawabkan. Akuntabilitas dikaitkan dengan pelaksanaan bimbingan dan konseling sebagai bentuk pertanggungjawaban atas hasil yang dicapai pada setiap program yang ditawarkan. Akuntabilitas berbeda arti dengan responbilitas. Akuntabilitas lebih mengarah kepada pertanggungjawaban keberhasilan atau kegagalan pencapaian organisasi yang telah dimiliki sedangkan akuntabilitas lebih kepada mempertanggungjawabkan pelaksanaan wewenang atau amanah tersebut.

Konselor berkewajiban untuk menjelaskan kinerjanya kepada stake holder, kepada pihak-pihak yang memiliki hak untuk meminta pertanggungjawaban atas kewenangan yang telah diberikan dalam mengelola sumber daya tertentu. Sumber daya yang dimaksud berorientasi pada prestasi akademik, perkembangan pribadi/sosial dan juga pada karir konseli/peserta didik. Prinsip ini bisa diartikan bahwa rumusan perilaku yang hendak dicapai, sistem intervensi psikoeduatif dan asessment merupakan komponen terkait dalam akuntabilitas proses bimbingan dan konseling di sekolah (Kartadinata, 2004).

\section{Kompetensi}

Kompetensi secara umum kecakapan seseorang dalam melaksanakan tugas atau pekrjaan yang disandangnya. Menurut Spencer (dalam Moehoeriono, 2009) kompetensi merupakan suatu karaktristik dasar seseorang yang terkait dengan efektifitas kinerja individu di dalam pekerjaannya atau karakteristik dasar individu yang memiliki hubungan sebab-akibat dengan kriteria yang dijadikan acuan, efektif atau berkinerja prima di tempat dia bekerja atau pada situasi tertentu.

Soedarmanto dalam bukunya Kinerja dan pengembangan SDM berpendapat bahwa kompetensi merupakan suatu atribut untuk melekatkan sumber daya manusia yang berkualitas dan unggul. Atribut yang dimaksud adalah kualitas yang diberikan pada orang atau benda, yang mengacu pada sejumlah karakteristik tertentu yang diperlukan seseorang untuk dapat melaksanakan suatu pekerjaan secara efektif. Pengetahuan, keterampilan dan keahlian itulah atribut yang harus dimiliki pekerja.
Dapat disimpulkan kompetensi adalah karakteristik atau cirri mendasar yang dimiliki oleh seseorang yang dapat meningkatkan kinerja dalam melakukan pekerjaan yang menjadi tanggungjawabnya.

\section{Etis}

Kata etis dalam KBBI memiliki arti sesuai etika atau sesuai denga asas peilaku yang disepakati secara umum. Suatu profesi akan eksis di masyarakat jika memperoleh public trust (kepercayaan public). Ramburambu yang dipergunakan disebut dengan kode etik. Kode etik bimbingan dan konseling Indonesia menjadi landasan moral dan rujukan, pedoman bagaimana bertingkah laku professional. Kode etik profesi harus dijunjung tinggi, diamalkan dan diamankan oleh anggota profesi Bimbingan dan Konseling Indonesia.Pada dasarnya kode etik memiliki fungsi ganda yaitu sebagai perlindungan dan pengembangan bagi profesi. Gibson dan Michel (1945) menuliskan perlunya mementingkan kode etik sebagai pedoman pelaksanaan tugas profesional. Kode etik merupakan tatanan etika yang telah disepakati dan harus dilaksanakan oleh profesi untuk memberikan pelayanan terbaik.

\section{Media Sosial}

Media sosial ialah sebuah media online yang memungkinkan adanya hubungan yang intens antar individu dengan menggunakan teknologi berbasis web. Media sosial dapat menjadi wadah berubahnya pola komunikasi satu arah menuju dialog interaktif. Teknologi yang serba canggih membuat penggunanya mampu dengan mudah berinteraksi, bertukar pesan, cerita dalam bentuk blog, jejaring sosial, wiki/ensiklopedia online, forum-forum maya, termasuk di dalamnya bentuk virtual worlds. Media sosial berbasis pada teknologi internet, yang membentuk pola komunikasi dan penyebaran informasi dari satu ke banyak audiens ataupun lebih dari itu (McMillan, 2006 dalam Sutijono 2018).

Menurut Kaplan dan Haenlein media sosial terbagi pada enam jenis yang berbeda. Media tersebut adalah:proyek kolaborasi (contoh: wikipedia), blog dan micro blog (missal: twitter), jenis media komunitas konten (misalnya you tube), situs jaringan sosial (misalnya facebook), virtual game (misalnya world of warcraft), dan virtual sosial (misalnya second life). Fungsi dari sosial media sendiri adalah untuk bersosialisasi, memperluas interaksi social antar manusia dengan menggunakan internet dan teknologi web, mentransformasi praktik komunikasi menjadi dialogis antar banyak audience dan mendukung demokratisasi pengetahuan dan informasi.

\section{PEMBAHASAN}

Profesi konselor adalah pekerjaan sosial kontemporer dimana pelakunya diharuskan untuk beradaptasi secara cepat dengan lingkungan sosial dan klien yang berbeda. Menghadapi generasi milenial yang memiliki karakteristik unik konselor sekolah harus mampu menangkap titik sehingga terjadi "klik" yang menghubungkan dengan dunia generasi milenial. 
Penelitian yang dilakukan oleh Putra (2016) menunjukkan adanya perbedaan karakteristik yang signifikan antara generasi $\mathrm{Z}$ dengan generasi lain terutama dalam penggunaan dan penguasaan teknologi.

Generasi milenial memiliki kecenderungan pada karakteristik berikut:

1. Percaya pada teknologi

2. Jaga Image

3. Serba bisa

4. Terbuka pada perubahan

5. Percaya diri

6. Berorientasi pada Tim

7. Kaya Informasi

8. Tidak sabaran

9. Mudah beradaptasi

Seorang konselor sekolah adalah tenaga profesional pendidikan yang bertugas membantu siswa dalam upaya berkembang secara optimal, menemukan jati dirinya, melakukan penyesuaian/adaptasi terhadap lingkungan serta mampu merencanakan masa depannya dengan baik. Prayitno (2004) menjelaskan bahwa pada hakikatnya pelaksanaan Bimbingan dan Konseling di sekolah adalah untuk mencapai tiga kesuksesan (tri sukses) yaitu sukses akademik, sukses dalam persiapan karir dan juga sukses dalam hubungan kemasyarakatan di lingkungan individu tersebut berada.

Layanan Bimbingan dan Konseling berada dalam ranah psikopedagogis dalam konteks budaya, nilai dan religi yang diyakini konseli dan konselor. Karena sifat normatif pedagogis inilah fokus orientasi pelayanan Bimbingan dan Konseling adalah pengembangan perilaku yang seharusnya dikuasai oleh individu untuk jangka panjang; menyangkut proses perilaku pendidikan, karier , pribadi, keluarga dan juga proses pengambilan keputusan (Kartadinata, 2004).

Pelaksanaan Bimbingan dan Konseling di sekolah terutama menghadapi generasi Milenial perlu difokuskan pada bagaimana melayani mereka dengan "tune in" pada frekuensi yang sama. Hal ini bisa dilakukan dengan penggunaan media sosial. Semisal menggunakan Vlog untuk memberikan tutorial materi tertentu, memberikan motivasi atau mengenalkan suatu konsep baru. Cyber Counseling juga merupakan pilihan lain yang bisa diambil konselor sekolah. Proses konsultasi dan konseling tidak lagi harus mensyaratkan tatap muka akan tetapi bisa dilakukan melalui email, whattsapp, video call atau media sosial lain. Konselor perlu mengimbangi pemikiran generasi milenial yang menggunakan frame logika fresh ad youth.

Sebagai tenaga professional yang memberikan layanan bimbingan dan konseling etika konselor telah diatur dalam regulasi perilaku profesional yang jelas. Kekuatan dan eksistensi suatu profesi tergantung kepada kepercayaan publik. Persepsi publik setiap saat bisa bergeser dan berbalik arah karena adalanya malpraktik, perilaku tidak etis dan tidak profesional. Disinilah kode etik berfungsi sebagai self regulation yang berfungsi melindungi dari campur tangan pemerintah atau justru ketidaksepakatan internal profesi.

Kesadaran akan perilaku etis ini dibangun sejak proses profesionalisasi, sertifikasi dan akreditasi. Artinya layanan bimbingan dan konseling akan terlaksana secara profesional karena dilakukan oleh konselor yang bersertifikat dan kompeten. Terkait kompetensi seorang konselor sekolah perlu menguasai kompetensi bersama (common competencies) dan kompetensi khusus (core/specific competencies).

Kartadinata (2004) menjelaskan kompetensi yang harus dimiliki konselor sebagai pendidik psikologis:

1. Konselor memahami kompleksitas interaksi antara individu dan lingkungan dalam ragam konteks sosial budaya

2. Konselor harus menguasai jenis intervensi psiologis baik antar maupun intrapribadi dan lintas budaya

3. Konselor memiliki penguasaan strategi dan teknik asesmen sehingga difahami keberfungsian psikologis individu dan interaksinya dengan lingkungan

4. Konselor memahami proses perkembangan manusia secara individual dan sosial.

5. Konselor memegang teguh regulasi profesi

6. Konselor menguasai kaidah-kaidah dan praktik pendidikan.

Sikap profesionalisme yang ditunjukkan dengan kemampuan melaksanakan akuntabilitas, penguasaan kompetensi bersama dan khusus, kemampuan berperilaku etis dan memberikan pelayanan terupdate melalui sosial media akan menjadikan "jurang" antara konselor sekolah dan generasi milenial akan terseberangi dengan langkah pasti.

\section{PENUTUP}

\section{Simpulan}

Menghadapi peserta didik di era digital konselor sekolah wajib menciptakan berbagai inovasi dan menggunakan teknologi dalam pemberian layanan. Memaksimalkan penggunaan media sosial akan sangat membantu dalam melayani generasi milenial yang jumlahnya cukup besar tanpa harus melakukan tatap muka. Untuk itulah penguasaan wawasan, pengetahuan, nilai, sikap dan referensi tentang teknologi informasi, dan pemahaman piranti lunak dan keras mutlak diperlukan. Konselor di jaman milenial idealnya memiliki kemampuan di bidang IT terutama pelaksanaan pelayanan BK yang berorientasi pada jaringan dengan memanfaatkan teknologi informasi. 


\section{Saran}

Konselor sekolah bisa menggunakan cyber counseling berupa penggunaan media sosial dalam memberikan pelayanan kepada siswa. Tetapi hal ini juga perlu disertai pemahaman kepada siswa akan penggunaan secara bijak, cerdas, logis dan kritis terhadap informasi dari sosial media. Layanan Bimbingan dan Konseling bisa menggunakan media interaktif seperti film, vlog, teleconference, macromedia flash, educative game dan $\mathrm{e}-$ counseling.

\section{DAFTAR PUSTAKA}

Anoraga, Pandji. 2009. Psikologi Kerja. Semarang: Rineka Cipta

Firman, F. (2019). Strategi Dan Pendekatan Pelaksanaan Bimbingan Konseling Di Sekolah Untuk Menghadapi Revolusi Industri 4.0.

Harefa, Andrias. 2004. Membangkitkan Roh/etos Profesionalisme. Jakarta: Gramedia

https://ms.wikipedia.org/wiki/Profesionalisme diakses di Bojonegoro jawa Timur pada 29 September 2018.

Kartadinata, Sunaryo. 2004. Arah dan tantangan Bimbingan dankonseling Profesional: Proposisi Historik-Futuristik. Bandung:UPI.

Kurniawan, Agung. 2005. Transformasi Pelayanan Publik. Yogyakarta: Pembaruan.

Maryulis. 2014. Pengaruh Aktivitas di Media sosial terhadap rutinitas Blogger Sumatera Barat dalam Jurnal perkomnas, Vol 17, No. 2 hlm 119-128. https://media.neliti.com/media/publications/222380pengaruh-aktivitas-di-media-sosial-terha.pdf, diakses di Bojonegoro Jawa Timur pada 29 September 2018.

Moeheriono. 2009. Pengukuran Kinerja Berbasis Kompetensi. Bogor:Ghalia

Peraturan bersama Menteri Pendidikan Nasional dan Kepala BKN No.03 /V/PB/2010/No.14 tahun 2010 tentang Petunjuk Pelaksanaan Jabatan Fungsional Guru dan Angka Kreditnya. Tersedia on line Https://luk.staff.ugm_ac.id. Diakses pada 30 September 2018

Prayitno. 2004. Dasar-dasar Bimbingan dan konseling Islam. Jakarta: Rineka Cipta

Putra, Yanuar Surya. 2016. Theoritical review:Teori Perbedaan Genersi. Among Makarti Vol.9 No. 18 tersedia online di jurnal

Siagian Sondang P. 2009. Administrasi Pembangunan. Jakarta: Bumi Aksara.

Soedarmanto. 2009. Kinerja dan Pengembangan Kompetensi SDM. Yogyakarta:Pustaka Pelajar

Sutijono \&Farid, Dimas Ardika Miftah. 2018. Cyber Counseling di Era Generasi Milenial dalam Jurnal Sosio Humanika Tersedia online di journals.mindamas.com diakses di Bojonegoro Jawa Timur pada 28 September 2018.

Undang-undang No. 20 tahun 2003 tentang Sistem Pendidikan Nasional tersedia online di kelembagaan.ristekdikti.go.id, di akses di Bojonegoro Jawa Timur pada 28 September 2018. 